TITLE:

Nautiliniellid Polychaetes Living in the Mantle Cavity of Bivalve Mollusks from Cold Seeps and Hydrothermal Vents around Japan

AUTHOR(S):

Miura, Tomoyuki; Hashimoto, Jun

CITATION:

Miura, Tomoyuki ... [et al]. Nautiliniellid Polychaetes Living in the Mantle Cavity of Bivalve Mollusks from Cold Seeps and Hydrothermal Vents around Japan. PUBLICATIONS OF THE SETO MARINE BIOLOGICAL LABORATORY 1996, 37(3-6): 257-274

ISSUE DATE:

1996-12-25

URL:

http://hdl.handle.net/2433/176264

RIGHT: 


\title{
Nautiliniellid Polychaetes Living in the Mantle Cavity of Bivalve Mollusks from Cold Seeps and Hydrothermal Vents around Japan
}

\author{
TOMOYUKI MIURA \\ Faculty of Fisheries, Kagoshima University, 4-50-20, \\ Shimoarata, Kagoshima 890, Japan \\ and \\ Jun Hashimoto \\ Japan Marine Science and Technology Center, 2-15 Natsushima-cho, \\ Yokosuka 237, Japan
}

\begin{abstract}
Two new genera and four new species of nautiliniellid polychaetes living in the mantle cavity of bivalve mollusks are described from cold seeps and hydrothermal vents around Japan. Iheyomytilidicola tridentatus, n. gen., n. sp. from the Iheya Ridge of the Okinawa Trough, has three kinds of setae and differs from other nautiliniellid polychaetes that have one or two kinds of setae. Thyasiridicola branchiatus, n. gen., $\mathrm{n}$. sp. found on gill filaments of a deep-sea thyasirid clam from the Hatsushima cold seep in Sagami Bay, has elongated notopodia and less developed tentacular segment. This new genus is unique in the family in having an achaetous tentacular segment with both dorsal and ventral cirri. Shinkai semilonga, n. sp. from the Minami-Ensei Knoll of the Okinawa Trough, differs from other congeneric species in having more than five simple hooks on each parapodium. Natsushima graciliceps, n. sp. from Kagoshima Bay differs from $N$. bifurcata in having enlarged notopodia in the mid-body region instead of lacking them. In addition, S. sagamiensis, S. longipedata, and $N$. bifurcata are reported with new records, remarks, and biological notes.
\end{abstract}

Key words: Polychaeta, Nautiliniellidae, Iheyomytilidicola, Thyasiridicola, Natsushima, Shinkai, taxonomy, sexual dimorphism, symbiosis.

\section{Introduction}

A few polychaetes have been reported to live in association with bivalves mollusks in shallow waters. Antonbruunia viridis Hartman \& Boss, 1966 lives within the mantle cavity of a bivalve mollusk, Lucina fosteri Hartman \& Boss, 1966, collected from the depths of 68$82 \mathrm{~m}$ (Hartman \& Boss, 1966). A polynoid species, Harmothoe commensalis Rozbaczylo \& Cañete, 1993, inhabits the mantle cavities of two subtidal clams, Gari solida (Gray, 1828) and Semele solida (Gray, 1828), on the Chilean coast (Rozbaczylo \& Cañete, 1993). In contrast, numerous polychaetes are known as symbiotic with deep-sea bivalve mollusks. Dean (1992) has described an arabellid polychaete, Pholadiphila turnerae Dean, 1992 from two species of wood boring bivalves collected from experimental wood panels submerged at a depth of 3602 $\mathrm{m}$ off Massachusetts. Three species of branchiate polynoids commensal with mytilid mussels have been reported from the Galapagos Rift (Pettibone, 1984), the Florida Escarpment (Pettibone, 1986), the Okinawa Trough, and the Kaikata Seamount (Miura \& Hashimoto, 1991). Nautiliniellid polychaetes have been found living in the mantle cavity of deep-sea bivalves of the families, Solemyidae (Acharax), Mytilidae (Bathymodiolus, unidentified genus close to Adula), Thyasiridae (Thyasira, Conchocele), and Vesicomyidae (Calyptogena), from hydrothermal vents and cold seeps (Blake, 1990; Miura \& Hashimoto, 
1993; Miura \& Laubier, 1989, 1990; Miura \& Ohta, 1990). Blake (1993) has described four new genera from the Eastern Pacific and the Gulf of Mexico.

Japanese cold seeps and hydrothermal vents have been surveyed using a deep submergence research vehicle (DSRV) "Shinkai 2000", a remotely operated vehicle (ROV) "Dolphin $3 K "$, and a deep towed camera system (DTC) with a small dredge. In this study, we report the occurrence of seven nautiliniellid polychaete species, including two new genera and four new species, from Japanese waters. The types and additional specimens are deposited in the National Science Museum, Tokyo (NSMT), the National Museum of Natural History, Smithsonian Institution (USNM), the Los Angeles County Museum of Natural History (LACM-AHF), and the Japan Marine Science and Technology Center (JAMSTEC).

\section{Terminology}

Tentacular segment.

The terminology of the head region includes considerable confusion in some previous descriptions of nautiliniellid polychaetes. The segment next to the prostomium has been represented as the first setiger (Miura \& Laubier, 1989, 1990; Miura \& Ohta, 1990), as the second or tentacular segment (Miura \& Hashimoto, 1993), and as the peristomial segment (Blake, 1993).

The head of nautiliniellid polychaetes consists of the prostomium and a modified body segment. The segment next to the prostomium is peristomial, tentacular and setigerous in general. As indicated by Blake (1993), it is a true segment similar to following body segments, but often reduced and fused partially with the prostomium. The peristomial rings, segment-like structures next to the prostomium, in eunicid and some other polychaetes are known ontogenetically as a presegmental area and lack any setae ( $\AA$ kesson, 1967; Fauchald, 1992; Miura, 1986). The nautiliniellid segment next to the prostomium differs from these peristomial rings in having setae or sometimes complete parapodia. To avoid the confusion, we do not use the term peristomium or peristomial ring for the segment next to the prostomium in nautiliniellid species. In this study, we apply the term tentacular segment for the segment next to the prostomium (Fig. 1a). The tentacular segment is included in the segmental count as the first one.

Subbiramous parapodia.

The state of nautiliniellid parapodia has been expressed as subbiramous in the previous studies (Blake, 1990; Miura \& Hashimoto, 1993; Miura \& Laubier, 1989, 1990; Miura \& Ohta, 1990) and as sesquiramous in some species by Blake (1993). According to the glossary of technical terms in Day's monograph (Day, 1967), the subbiramous parapodium represents a parapodium which is neither completely uniramous nor biramous and the sesquiramous parapodium means a parapodium the notopodium of which is reduced to a dorsal cirrus, an acicula and one or two setae. As none of nautiliniellid polychaetes has notosetae, the parapodia should be expressed as subbiramous, but not as sesquiramous (Fig. 1b).

Neuropodial hook.

Nautiliniellid polychaetes are characterized by the presence of a simple seta with a distal fang (Miura \& Laubier, 1989, 1990). We use the term neuropodial hook for this characteristic simple seta found in all nautiliniellid species. In some species described by Blake (1993), the neuropodial hook has been confused with the additional neuroseta or even with the extruded neuroacicula, however these setae should be differently termed because of their taxonomical importance. 

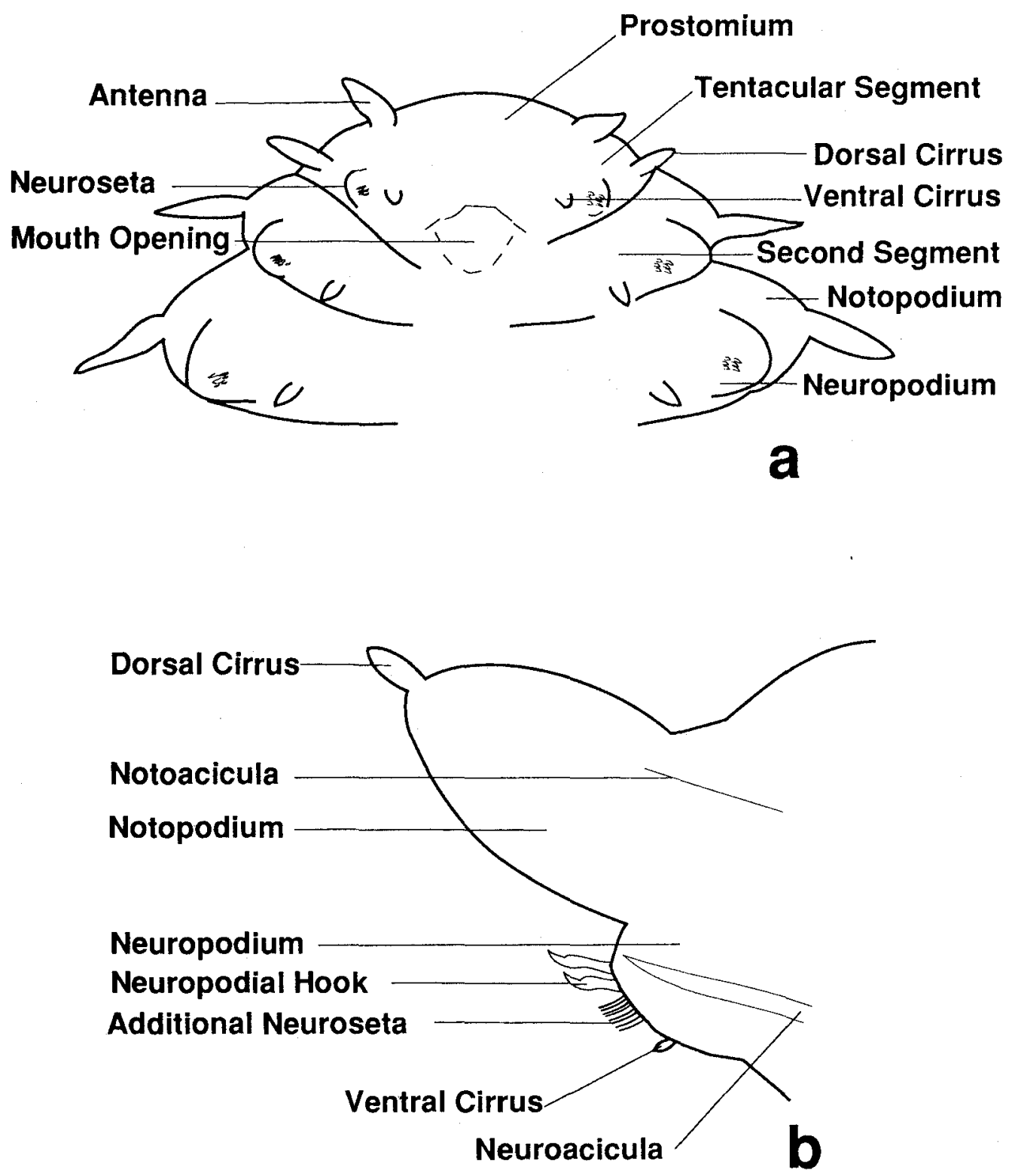

Fig. 1. Schematic drawing of nautiliniellid polychaete showing some morphological terms used in this study. a, ventral view of anterior end; b, parapodium.

\section{Taxonomic Account}

Family Nautiliniellidae Miura \& Laubier, 1990, emended

Type genus. Nautiliniella Miura \& Laubier, 1990

Emended diagnosis. Body long, vermiform, tapering posteriorly, with numerous setigerous segments; body in cross-section flattened ventrally, arched dorsally. Segmentation distinct. Prostomium usually with paired antennae; other remarkable occipital appendages absent. 
Tentacular segment partially fused with prostomium, with fully or less developed parapodia. Foregut with muscularized part. Parapodia subbiramous; notopodia usually reduced, sometimes enflated, without setae; neuropodia well-developed, supported by stout neuroacicula, with neurosetae. Neuropodial hook simple, with distal fang; additional neurosetae one to two kinds if present. Pygidium simple, without appendages.

Remarks. The name Nautilina proposed by Miura \& Laubier (1989) for the first nautiliniellid genus from the Japan Trench is preoccupied. The type genus was renamed as Nautiliniel$l a$ in the second publication that included the descriptions of two other genera and species from the Hatsushima cold seep as well (Miura \& Laubier, 1990). Blake (1990) described another nautiliniellid species from the Laurentian Fan in the Western North Atlantic. Three additional species have been described from the mantle cavities of mytilid and vesicomyid bivalves from the Iheya Ridge and the Minami-Ensei Knoll of the Okinawa Trough (Miura \& Hashimoto, 1993; Miura \& Ohta, 1991), and Blake (1993) has recently assigned four new North American genera and species to the family. The family diagnosis is thus emended on the basis of these recent studies as well as genera and species which will newly be described in the present study.

\section{Shinkai Miura \& Laubier, 1990, emended}

Type species. Shinkai sagamiensis Miura \& Laubier, 1990.

Gender. Feminine.

Emended diagnosis. Body long, tapering posteriorly, flattened ventrally, arched dorsally, with numerous setigerous segments. Prostomium short, with pair of antennae, without eyes. Tentacular segment fused with prostomium, with dorsal cirri, ventral cirri, neurosetae, and neuroaciculae. Foregut with strongly muscularized part. Parapodia subbiramous; notopodia sometimes elongated, with dorsal cirri and slender notoacicula; neuropodia short, with ventral cirri, neurosetae, and stout neuroacicula. Neuropodial hooks stout; additional setae absent. Pygidium cylindrical, without appendages.

Remarks. This diagnosis is emended to accommodate a new species discovered in the Okinawa Trough.

\section{Shinkai sagamiensis Miura \& Laubier, 1990}

Shinkai sagamiensis Miura \& Laubier, 1990, p. 320, fig. 1 a-f.

Material. Hatsushima cold seep, Sagami Bay, DSRV Shinkai 2000 Dive 519, 12 Nov. 1990, 3400.0' $\mathrm{N}, 139^{\circ} 13.8^{\prime} \mathrm{E}, 1170 \mathrm{~m}$, associated with Calyptogena soyoae Okutani, 1957, 3 immature specimens (USNM 172132).

Biological note. Each of three bivalves among seven dissected was anchored by a single specimen of $S$. sagamiensis.

Shinkai longipedata Miura \& Ohta, 1991

(Figs. 2 \& 3)

Shinkai longipedata Miura \& Ohta, 1991, pp. 385-387, fig. 2 a-j.

Material. Iheya Ridge, Okinawa Trough, DSRV Shinkai 2000 Dive 613, 29 May 1992, 27 $33.0^{\circ} \mathrm{N}, 126^{\circ}$ $58.0^{\circ} \mathrm{E}, 1395 \mathrm{~m}$, associated with an undescribed species of Calyptogena, 12 specimens (USNM 172133: 6 males; USNM 172134: 6 females); same site, Dive 614, 30 May 1992, 13 specimens 


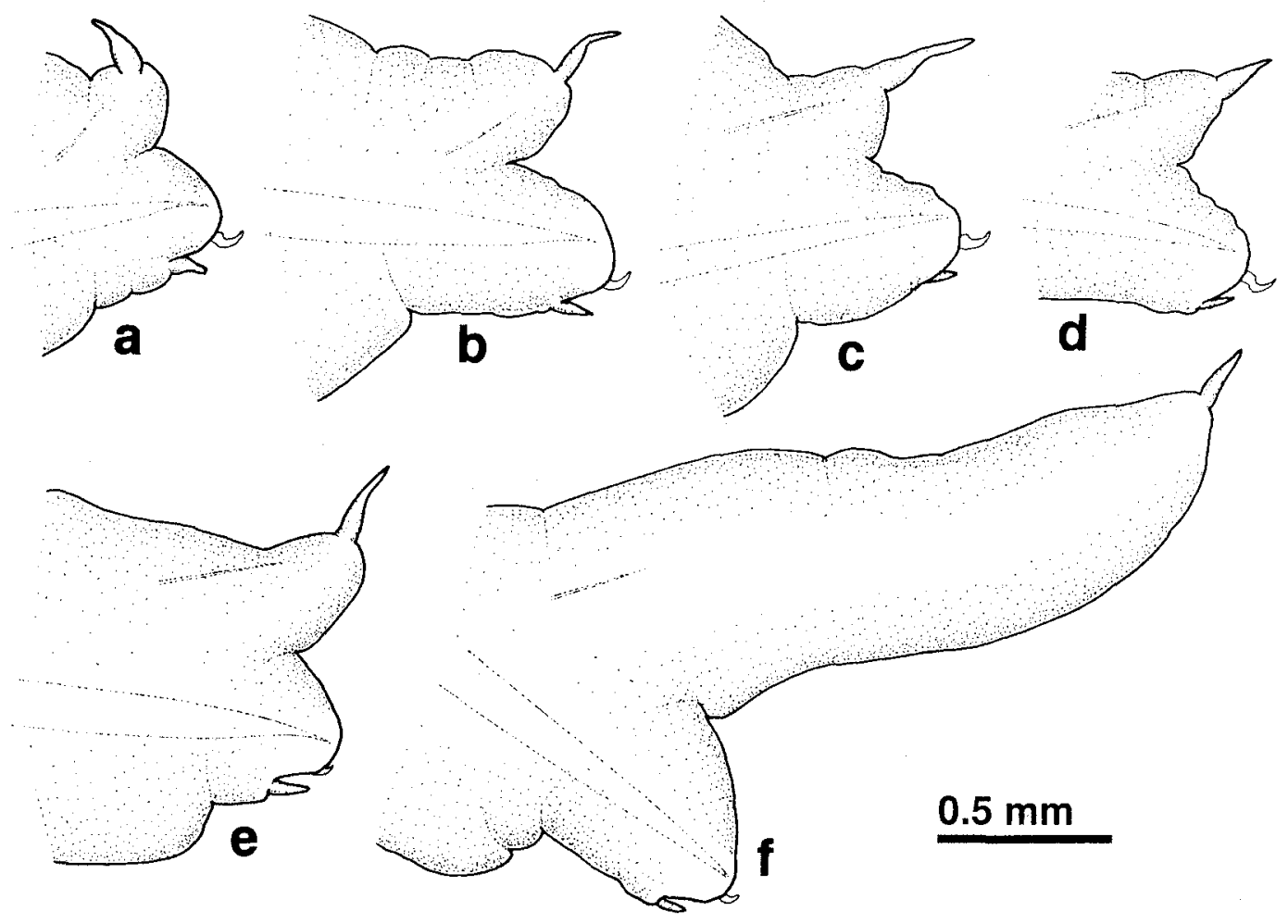

Fig. 2. Shinkai longipedata, a, parapodium of the 10th segment counted from the tentacular segment (parapodium 10) of a male specimen from the Iheya Ridge; b, parapodium 51 of the same; c, parapodium 100 of the same; $d$, parapodium 200 of the same; e, parapodium 10 of a female specimen from the same host bivalves as the above male, $f$, parapodium 100 of the female.

(LACM-AHF: 3 males \& 3 females, JAMSTEC: 3 males \& 4 females).

Biological note. Living specimens were observed to release gametes when detached from the host bivalves. Mature females had deep purplish brown parapodia with elongated notopodia (Fig. 2e,f) and clearly differed from the totally whitish mature males with short notopodia (Fig. 2a-d). The examined materials contained almost equal number of males and females distinguished by the above characters. The largest complete male was $163 \mathrm{~mm}$ long by $3.2 \mathrm{~mm}$ wide with 340 segments while the smallest complete female $115 \mathrm{~mm}$ long by $4.3 \mathrm{~mm}$ wide with 232 segments. The female was wider and tended to be longer than the male (Fig. $3)$.

In 31 Calyptogena specimens dissected to examine the presence of parasites, 11 contained 19 individuals of $S$. longipedata (other than these, six specimens were found from the sediment accumulated in the container of the bivalve samples). In six specimens of the 11 bivalve mollusks, we found two or more polychaetes including at least one male and one female in a single host. Similar occurrence of a large female polychaete paired with a dwarf male has also been reported for Antonbruunia viridis by Hartman \& Boss (1966). 


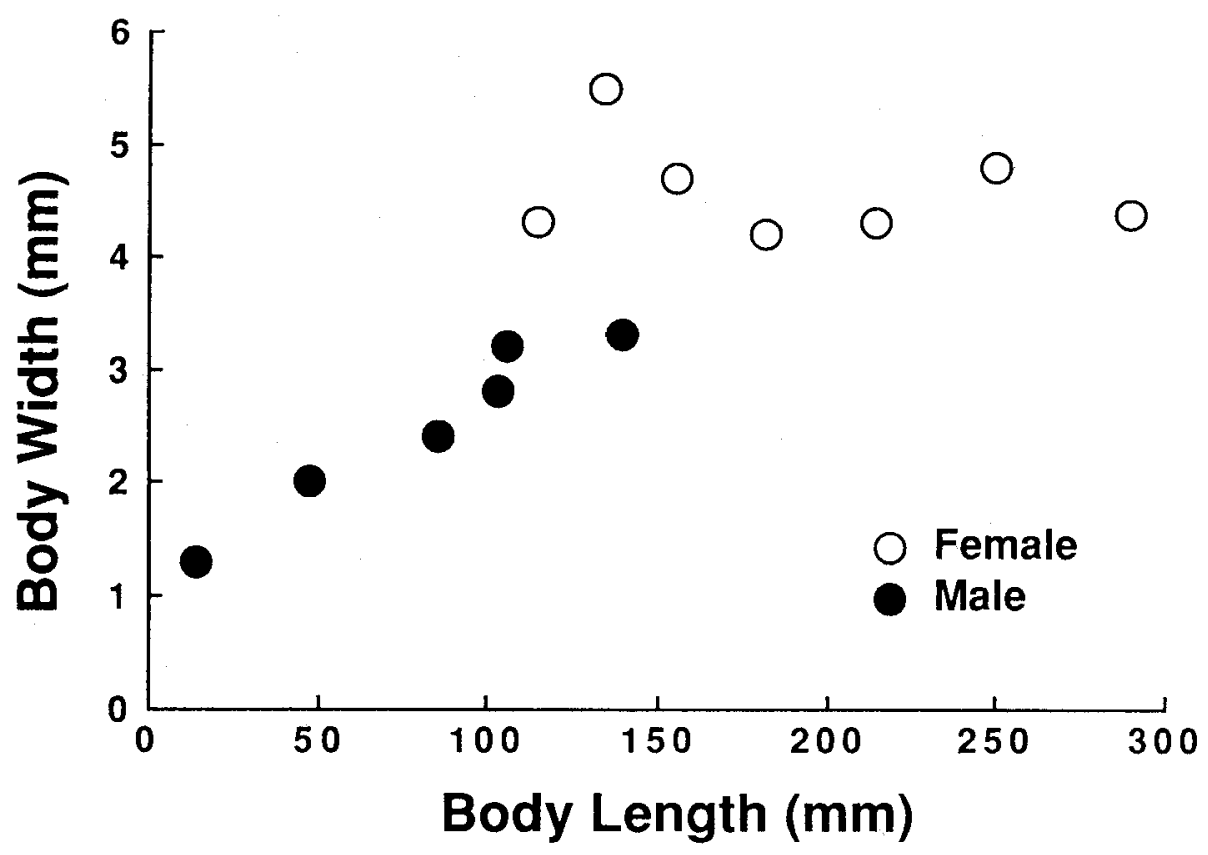

Fig. 3. Relationship between the body width and the body length in Shinkai longipedata, demonstrating sexual dimorphism.

\section{Shinkai semilonga, new species}

(Figs. 4-6)

Material. Minami-Ensei Knoll, Okinawa Trough, DSRV Shinkai 2000 Dive 616, 1 Jun. 1992, 28²3.5' $\mathrm{N}, 127^{\circ} 38.5^{\prime} \mathrm{E}, 625 \mathrm{~m}$, associated with Calyptogena solidissima Okutani et al, 1992, holotype (NSMT Pol. -H. 355: female), 25 paratypes (USNM 172129: 3 males \& 2 females, LACM-AHF POLY 1733: 5 males; LACM-AHF POLY 1734: 5 females, JAMSTEC: 5 males \& 5 females).

Description of holotype.

Holotype complete, $100 \mathrm{~mm}$ long, $3.9 \mathrm{~mm}$ wide including parapodia, with 267 segments. Body flattened ventrally, arched dorsally (Fig. $4 \mathrm{a}-\mathrm{c}$ ). Integument smooth. Preserved specimen pale, with dark parapodia.

Prostomium short, with pair of short antennae, without eyes (Fig. 4a,b). Tentacular segment well fused with prostomium, with dorsal cirri, ventral cirri, neuroacicula, and numerous neuropodial hooks (Fig. 4b,c). Foregut with strongly muscularized part. Pygidium rounded, without anal cirri (Fig. 4d).

Parapodia subbiramous, with dorsal and ventral cirri (Fig. 5). Notopodia slightly elongated, supported by single, very thin notoacicula; dorsal cirri short, on distal end of notopodia. Neuropodia well developed, supported by single, stout neuroacicula; ventral cirri on vento-posterior side of neuropodia, shorter than dorsal cirri.

Neuropodial hooks simple, stout, slightly curved on distal end (Fig. 4e); number of hooks per parapodium, about 15 on parapodia 1-3 (Fig. 5a), more than 25 on parapodia $4-6$ as maximum, then decreasing to reach about ten on parapodium 10 (Fig. $5 \mathrm{~b}$ ), five to eight on parapodia 50-200 (Fig. 5c-e).

Biological note. Sinkai semilonga did not exhibit sexual dimorphism (Figs. 5,6) except for 

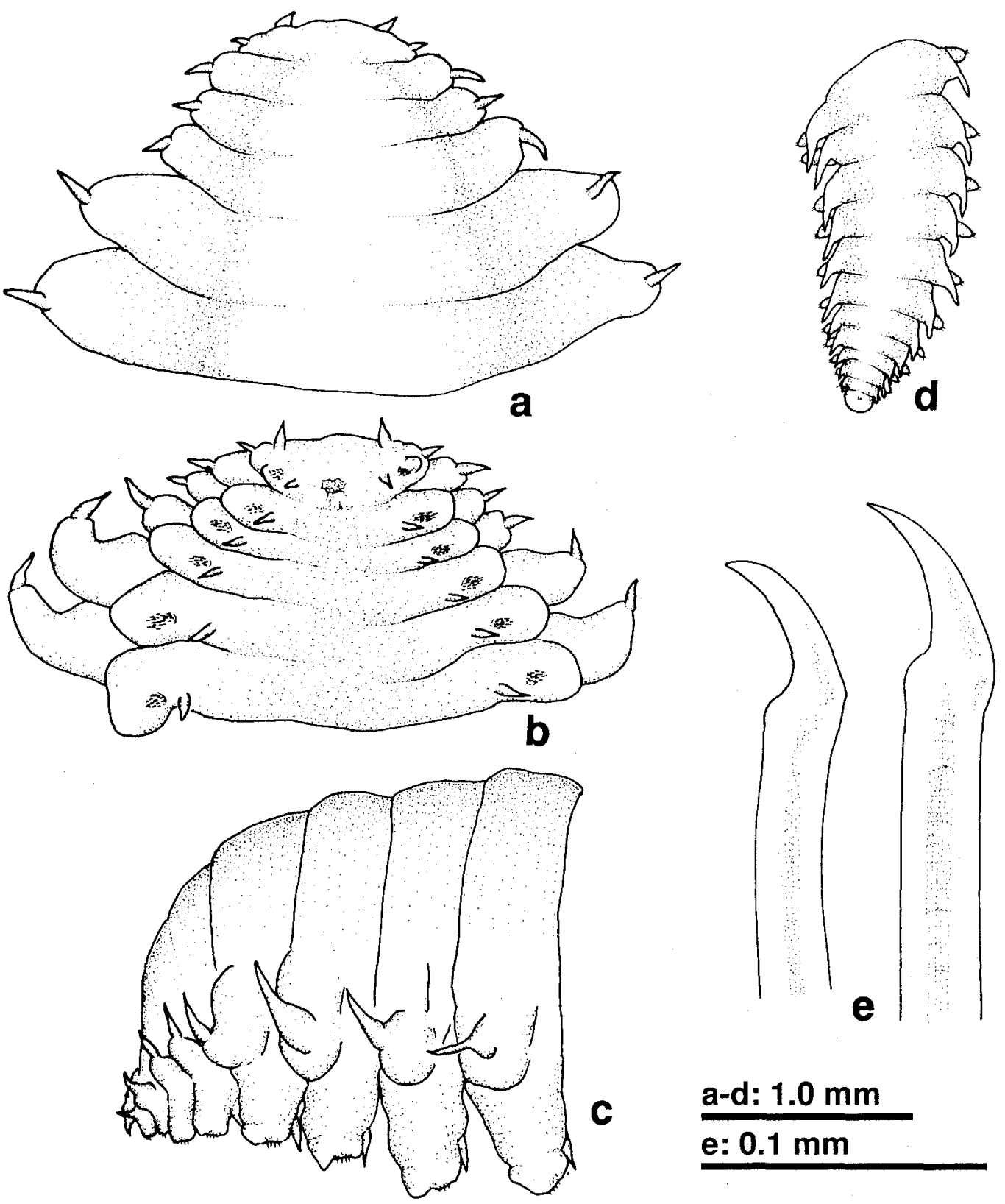

a-d: $1.0 \mathrm{~mm}$

\section{e: $0.1 \mathrm{~mm}$}

Fig. 4. Shinkai semilonga, new species (holotype). a, anterior end, dorsal view; $b$, same, ventral view ; c, same, lateral view; d, posterior end, dorsal view; e, neuropodial hooks from parapodia 51 (right) and 200 (left).

the body color of living specimens. The female of S. semilonga was deep purplish brown on parapodia, and the male whitish.

Remarks. The parapodia and the head region of S. semilonga are similar to those of the male specimens of $S$. longipedata. The shape of neuropodial hooks and their number in each 


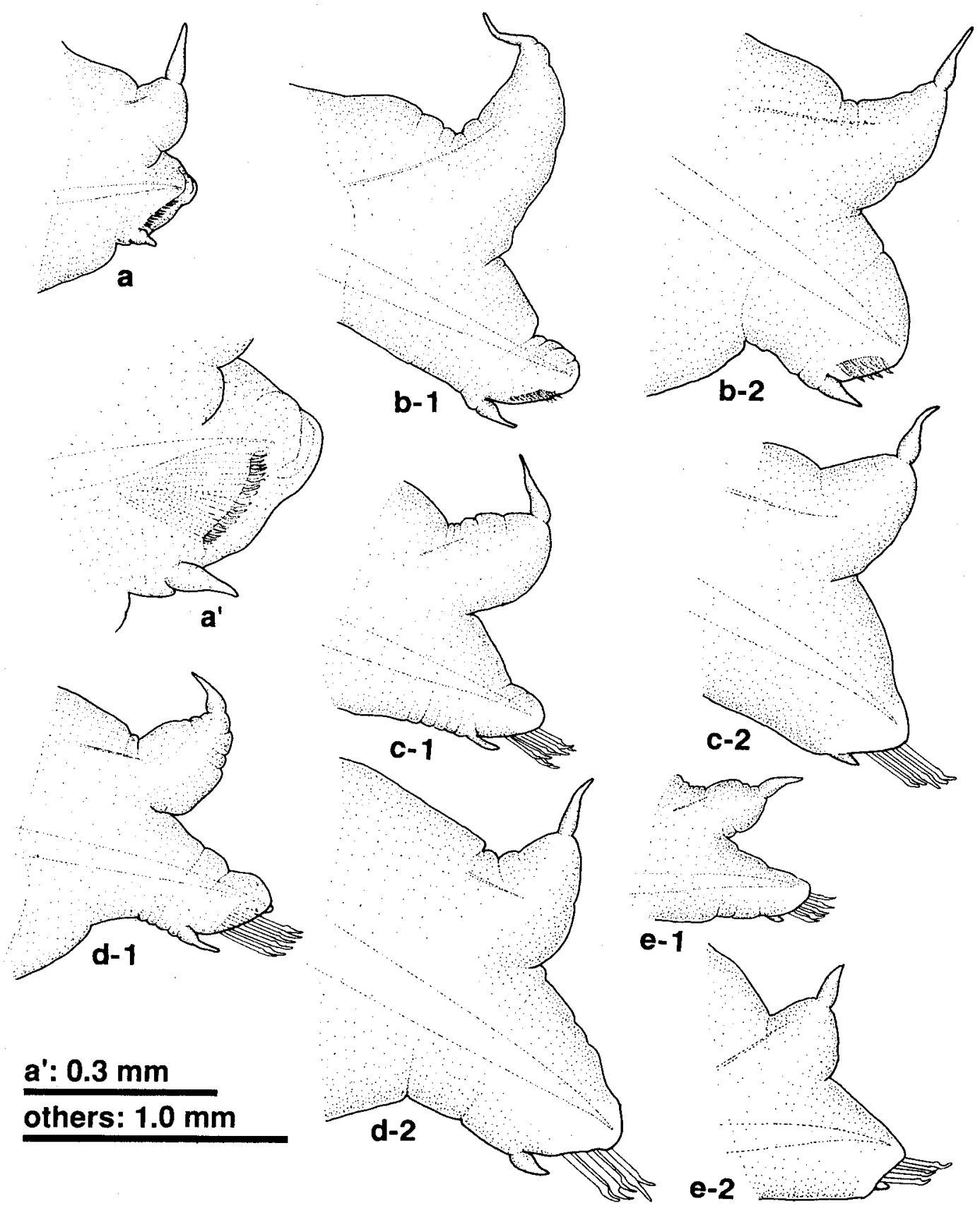

Fig. 5. Shinkai semilonga, new species. a, parapodium 4 of the holotype (female); a', Same, enlarged; $b-1$, parapodium 10 of the holotype; $b-2$, parapodium 10 of a male paratype; $c-1$, parapodium 51 of the holotype; $c-2$, parapodium 51 of the male; $d-1$, parapodium 100 of the holotype; $\mathrm{d}-2$, parapodium 100 of the male; $\mathrm{e}-1$, parapodium 200 of holotype; e-2, parapodium 200 of the male. 


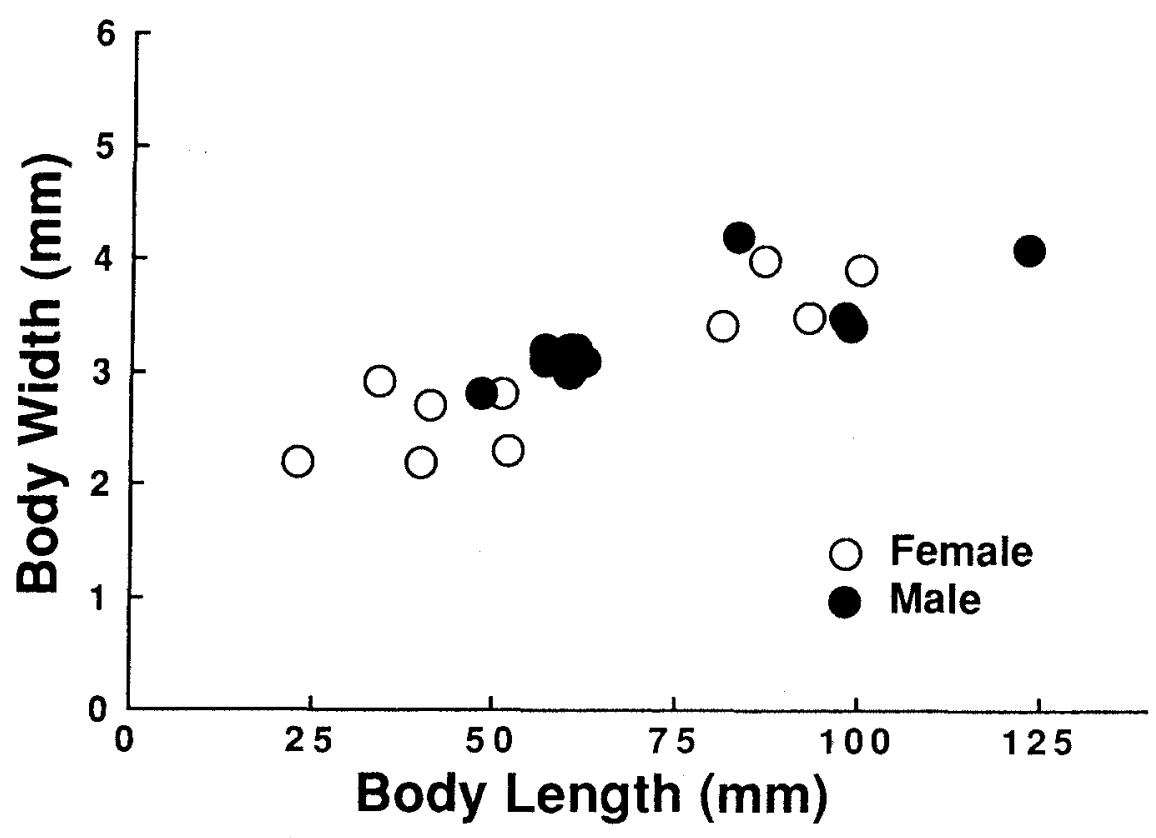

Fig. 6. Relationship between the body width and the body length in Shinkai semilonga, new species.

parapodium, however, are clearly different among congeneric species. In S. longipedata, middle or posterior parapodia are armed by a single neuropodial hook with a strongly curved distal fang (Fig. 2), whereas those of $S$. semilonga have more than five slightly curved hooks (Fig. 4). Shinkai sagamiensis differs from the above two species in having very short notopodia and strongly curved distal fangs on neuropodial hooks.

Etymology. The species name refers to the intermediate state in the dorsal cirri between $S$. sagamiensis and S. longipedata.

\section{Natsushima Miura \& Laubier, 1990, emended}

Type species. Natsushima bifurcata Miura \& Laubier, 1990.

Gender. Feminine.

Emended diagnosis. Body long, tapering posteriorly, flattened ventrally, arched dorsally, with numerous setigerous segments. Prostomium short, with pair of antennae, without eyes. Tentacular segment fused to prostomium, with dorsal cirri, ventral cirri, neurosetae, and neuroaciculae. Foregut with strongly muscularized part. Parapodia - subbiramous; notopodia short or elongated; notoacicula slender, sometimes absent; neuropodia short, with stout neuroacicula, neuropodial hooks, and additional setae. Pygidium cylindrical without appendages.

Remarks. The generic diagnosis is emended to accommodate a new species.

Natsushima bifurcata Miura \& Laubier, 1990

Natsushima bifurcata Miura \& Laubier, 1990, pp. 322-323, fig. 2 a-f. 
Material. Okino-yama cold seep, Sagami Bay, ROV Dolphin 3K, 17 May 1989, 3458.2'N, 139 31.4'E, $1114 \mathrm{~m}$, associated with Acharax johnsoni Dall, 1891, 1 immature specimen (USNM 172135).

Remarks on host. The host bivalve was misidentified as a species of the genus Solemya in the original description (Miura \& Laubier, 1990), but it has been corrected as Acharax johnsoni by Ohta (1990).

\section{Natsushima graciliceps, new species}

(Fig. 7)

Material. Kagoshima Bay, DTC Dredge, 6 Feb. 1993, 31'39.6’N, $130^{\circ} 48.1^{\prime} \mathrm{E}, 98 \mathrm{~m}$, associated with an undescribed solemyid bivalve of the genus tentatively identified as Solemya, holotype (NSMT Pol. -H. 356, female), 10 paratypes (USNM 172131: 3 females, LACM-AHF POLY 1736: 2 females, JAMSTEC: 2 females \& 3 incomplete).

Description of holotype.

Holotype female, ovigerous, $19.8 \mathrm{~mm}$ long, $1.7 \mathrm{~mm}$ wide including parapodia, with 115 segments. Body flattened ventrally, slightly arched dorsally (Fig. 7a-c); integument smooth. Color in preservative, pale; parapodia dark. Anterior segments inserted between paired branchial lamellae of host bivalves (Fig. 7h). Posterior segments more than twice as wide as anterior segments (Fig. 7a).

Prostomium short, with pair of short antennae, without eyes (Fig. 7b,c). Tentacular segment fused to prostomium, with dorsal and ventral cirri, and numerous neuropodial setae (Fig. 7c). Foregut with strongly muscularized part (Fig. 7b). Pygidium rounded, without anal cirri (Fig. 7a). Parapodia subbiramous. Notopodia with short dorsal cirri on distal end, without notoacicula, conical on anterior segments (Fig. 7d) ; elongated, cylindrical on posterior segments (Fig. 7e). Neuropodia supported by single stout neuroacicula, truncate; ventral cirri on ventro-posterior side of neuropodia, very short or rudimentary (Fig. 7d,e).

Neuropodial hooks simple, stout, slightly curved on distal end, with basal knobs (Fig. 7f); occurring up to three per parapodium throughout body. Additional neurosetae simple, bifurcate (Fig. 7g), occurring about ten per parapodium on anterior segments, more than 50 on posterior segments.

Variability. Paratypes varying from 5-22 mm long, 0.8-2.3 mm wide, with 62-144 segments. All specimens had narrow anterior segments and enlarged posterior segments. Mature females had posterior parapodia filled with oocytes (Fig. 7e). Mature male were not found.

Remarks. Natsushima graciliceps differs from N. bifurcata in having elongated notopodia on middle segments instead of short conical ones.

Etymology. The species name is derived from the slender anterior segments.

\section{Iheyomytilidicola, new genus}

Type species. Iheyomytilidicola tridentatus, new species.

Gender. Masculine.

Diagnosis. Body long, vermiform, tapering posteriorly, flattened ventrally, arched dorsally, with numerous setigerous segments. Prostomium short, with pair of antennae, without eyes. Tentacular segment completely fused with prostomium, with ventral cirri, lacking dorsal cirri and neurosetae. Foregut with strongly muscularized part. Parapodia subbiramous; notopodia with notoacicula and dorsal cirri; neuropodia supported by stout neuroacicula, with 


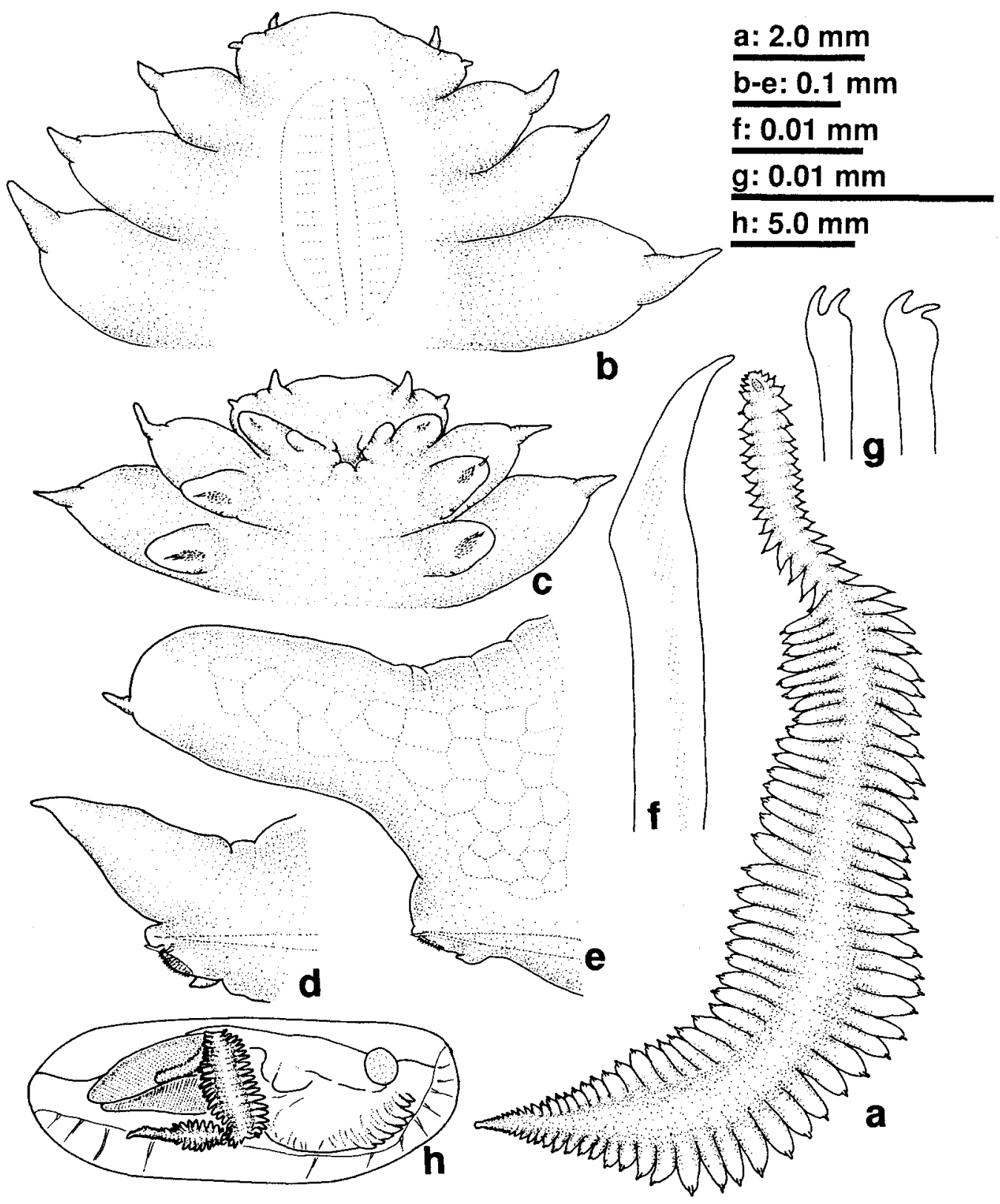

Fig. 7. Natsushima graciliceps, new species (holotype). a, whole body, dorsal view; b, anterior end, dorsal view; c, anterior end, ventral view; $d$, parapodium 9, anterior view; e, parapodium 40; $f$, neuropodial hook from parapodium $9 ; \mathrm{g}$, simple bifurcate hook from parapodium 9.

ventral cirri, neuropodial hooks, and two kinds of additional setae. Pygidium cylindrical, without appendages.

Remarks. In the nautiliniellid polychaetes, three species have a kind of additional neurosetae other than neuropodial hooks: Natsushima bifurcata and N. graciliceps have additional 
Table 1. Measurements of type specimens of Iheyomytilidicola tridentatus, new species. Each specimen was arranged with the host bivalve specimen represented by the first number of the first column.

\begin{tabular}{ccccl}
\hline No. & $\begin{array}{c}\text { Body Length } \\
(\mathrm{mm})\end{array}$ & $\begin{array}{c}\text { Body Width } \\
(\mathrm{mm})\end{array}$ & $\begin{array}{c}\text { Number of } \\
\text { Segments }\end{array}$ & Notes \\
\hline $1-1$ & 20.2 & 2.3 & 106 & female; holotype \\
$1-2$ & 17.1 & 2.0 & 93 & male; paratype \\
$3-1$ & 7.0 & 1.1 & 40 & immature; paratype \\
$3-2$ & 7.7 & 1.1 & 48 & immature; paratype \\
$3-3$ & 6.7 & 1.3 & 43 & immature; paratype \\
$4-1$ & 17.0 & 1.8 & 68 & immature; paratype \\
$4-2$ & 13.7 & 1.4 & 70 & immature; paratype \\
\hline
\end{tabular}

bifurcate setae, and Laubierus mucronata Blake, 1993 has subapically fringed mucronate setae (Blake, 1993). The new genus differs from all other nautiliniellids in having two kinds of additional setae.

Etymology. The genus name is derived from the type locality, the Iheya Ridge, and the host bivalve family, the Mytilidae.

\section{Iheyomytilidicola tridentatus, new species}

(Figs. 8 \& 9)

Material. Iheya Ridge, Okinawa Trough, DSRV Shinkai 2000 Dive 613, 29 May 1992, 27 $33.0^{\prime} \mathrm{N}, 126^{\circ}$ $58.0^{\prime} \mathrm{E}, 1395 \mathrm{~m}$, associated with Bathymodiolus aduloides Hashimoto \& Okutani, 1994, holotype (NSMT Pol. H-353: female), 6 paratypes (USNM 172130: 1 male \& 1 immature, LACM-AHF POLY 1735: : immature, JAMSTEC: 2 immature).

Description of holotype.

Holotype complete, $20.2 \mathrm{~mm}$ long, $2.3 \mathrm{~mm}$ wide including parapodia, with 106 segments. Body flattened ventrally, arched dorsally. Integument smooth. Preserved specimen pale.

Prostomium short, with pair of short cirriform antennae, without eyes (Fig. 8a,c). Tentacular segment completely fused to prostomium, lacking dorsal cirri and neurosetae; defined by ventral cirri (Fig. 8c,d). Foregut with strongly muscularized part. Pygidium rounded, without anal cirri (Fig. 8b).

Parapodia subbiramous throughout body, with very short dorsal and ventral cirri. Notopodia slightly inflated, supported by single stout notoacicula. Neuropodia supported by single stout neuroacicula, projected from parapodial base, slightly elongated on middle and posterior segments (Fig. 8e,f). Neuroacicula slightly stouter than notoacicula. Ventral cirri on vento-posterior side of neuropodia, decreasing in size on middle and posterior parapodia (Fig. 8f).

Neuropodial hooks on dorsal side of setal lobe, stout, slightly inflated subdistally, with minute projection on cutting edge of main fang (Fig. 9a); occurring up to five on each parapodium (Fig. 8e,f). Additional neurosetae two kinds; tridentate setae on outer base of setal lobe, simple, slender than neuropodial hooks, shorter than other setae, with blunt main tooth on one side of distal tip and two shorter blunt teeth on opposite side, occurring 10-20 per parapodium (Fig. 9b); minute slender setae on inner side of setal lobe, enlarged subdistally, with single distal mucronate spin, longer and more numerous than tridentate setae (Fig. 9c). 


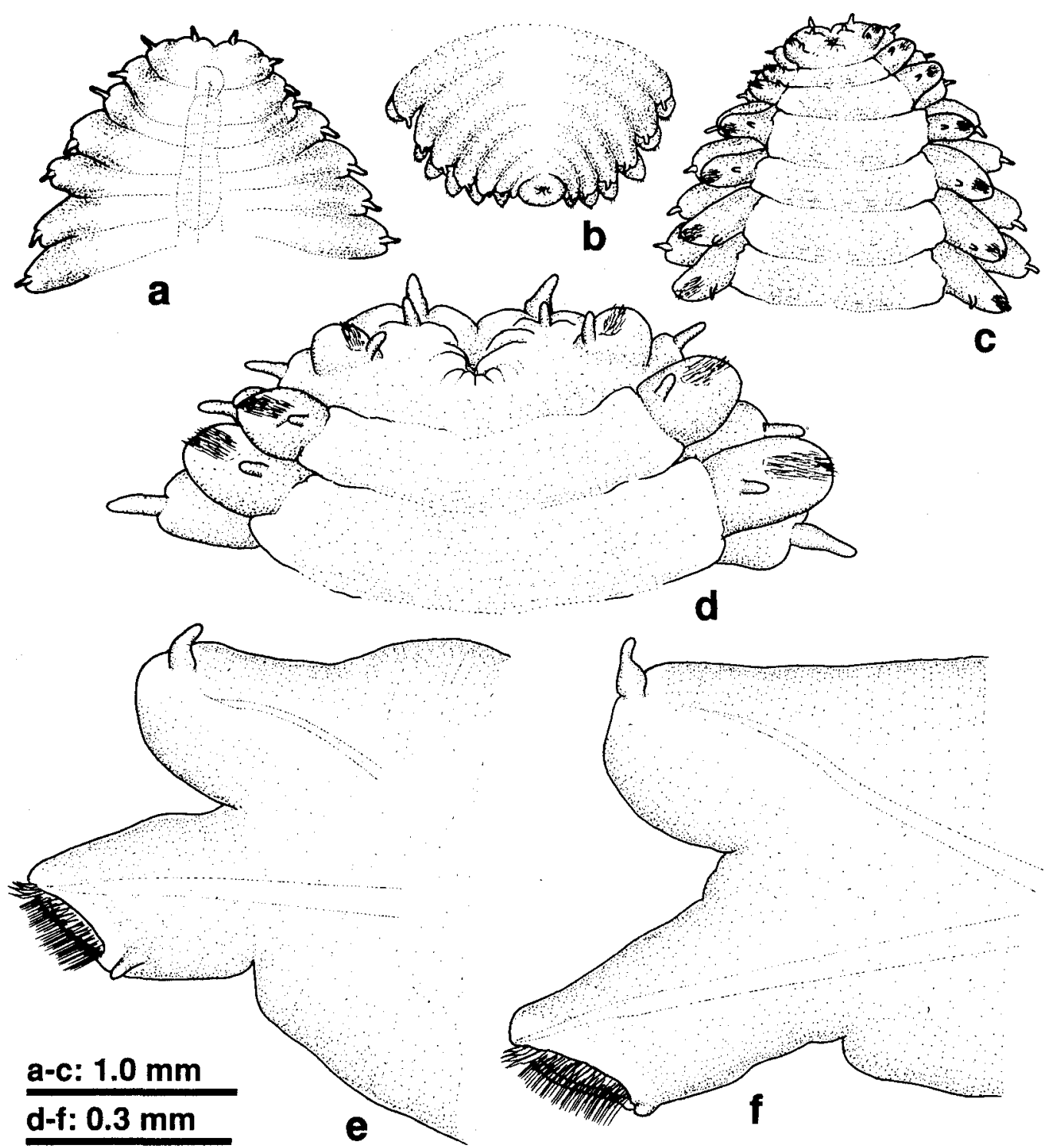

Fig. 8. Iheyomytilidicola tridentatus, new species (holotype). a, anterior end, dorsal view; b, posterior end, dorsal view; c, anterior end, ventral view; d, same, enlarged; e, parapodium 11; f, parapodium 40 .

Variability. The holotype is larger than paratypes (Table 1). Mature specimens were larger than $2.0 \mathrm{~mm}$ in body width. Tentacular segment is defined by the presence of ventral cirri in holotype (female) and male specimens (Fig. 8c,d). Additional to the ventral cirri, small juvenile specimens $(3-1,3-2$, and $3-3$ in Table 1 ) have embedded acicula on the tentacular segment (Fig. 9d).

Remarks. The new species is unique in the family in having three kinds of setae.

Etymology. The species name is derived from the characteristic tridentate setae. 


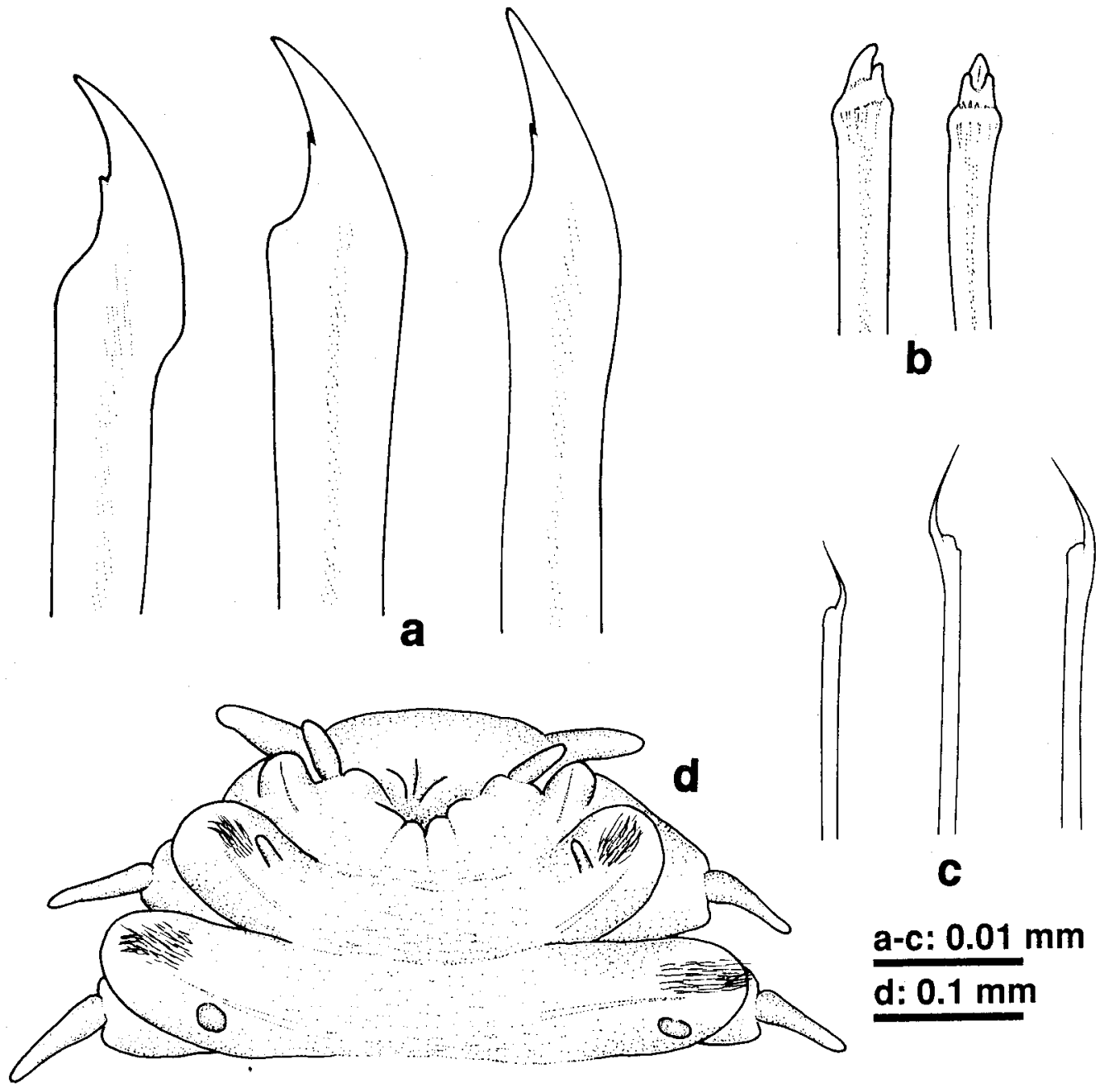

Fig. 9. Iheyomytilidicola tridentatus, new species. a, neuropodial hooks of the holotype; $b$, tridentate setae of the holotype, right-angled views; $c$, minute mucronate neurosetae of the holotype; $d$, anterior end of a juvenile paratype, ventral view.

\section{Thyasiridicola, new genus}

Type species. Thyasiridicola branchiatus, new species.

Gender. Masculine.

Diagnosis. Body long, vermiform, tapering anteriorly and posteriorly, flattened ventrally, strongly arched dorsally, with numerous setigerous segments. Prostomium short, with pair of antennae, without eyes. Tentacular segment fused with prostomium, with dorsal and ventral cirri, and embedded neuroacicula, lacking neurosetae. Foregut with strongly muscularized part. Parapodia subbiramous; notopodia supported by slender notoacicula, modified, branchia-like, with short dorsal cirri; neuropodia supported by stout neuroacicula, with ventral cirri and neuropodial hooks. Pygidium cylindrical, without appendages. 
Remarks. This genus is unique in the family in having an achaetous tentacular segment with both dorsal and ventral cirri.

Etymology. The generic name is derived from the host bivalve family, the Thyasiridae.

\section{Thyasiridicola branchiatus, new species}

(Fig. 10, a-g)

Material. Hatsushima cold seep, Sagami Bay, DSRV Shinkai 2000 Dive 316, 20 Nov. 1987, $34^{\circ} 00.0^{\prime} \mathrm{N}, 139^{\circ} 13.8^{\prime} \mathrm{E}, 1160 \mathrm{~m}$, associated with a thyasirid bivalve tentatively identified as Conchocele disjuncta Gabb, 1866, holotype (NSMT Pol. -H 354).

Description of holotype.

Holotype complete, $10 \mathrm{~mm}$ long, $1.5 \mathrm{~mm}$ wide including parapodia, with 69 segments. Body flattened ventrally, strongly arched dorsally (Fig. 10a). Integument smooth. Preserved specimen pale; notopodia of living specimen reddish.

Prostomium short, with pair of very short cirriform antennae, without eyes (Fig. 10c). Tentacular segment fused with prostomium, with dorsal cirri, ventral cirri, and embedded neuroacicula, lacking neurosetae; ventral cirri anterior to neuropodia (Fig. 10d). Foregut with strongly muscularized part. Pygidium rounded, without anal cirri (Fig. 10b).

Parapodia subbiramous throughout body, with small dorsal and ventral cirri; notopodia supported by single, slender notoacicula, branchia-like, elongated on posterior segments (Fig. 10e,f); neuropodia supported by single, stout neuroacicula, cylindrical.

Neuropodial hooks simple, stout, with slightly curved distal fang (Fig. 10g), occuring up to five per parapodium; several developing hooks embedded around acicula (Fig. 10e,f).

Remarks. Thyasiridicola branchiatus is similar to Flascarpia alvinae Blake, 1993 in having branchia-like notopodia (Blake, 1993). However the new species differs from the latter in the presence of the dorsal cirri on the tentacular segment and the slender notoacicula on each notopodium instead of their absence.

Etymology. The species name is derived from the branchia-like notopodial projection.

\section{Discussion}

Although Blake (1993) has described four new genera of the family Nautiliniellidae, the assignment of the genus Santelma into the family is questionable. The only known speceis, S. miraseta (Fauchald, 1992), was originally described as a species of the genus Pilargis in the family Pilargidae by Fauchald (1992). As their small bidentate neurosetae are similar to nautiliniellid neuropodial hooks, Blake (1993) redescribed the species and assigned it to a new nautiliniellid genus, Santelma. This species has a median antenna or its trace and abnormally extruded neuroacicula while it lacks parapodial cirri, neuropodial hooks, and a muscularized foregut. These features agree well with the family Pilargidae, but not with the Nautiliniellidae. The absence of palps, which was considered to be a good reason to remove the species from the Pilargidae by Blake (1993), may not be a sufficient testimony, because a pilargid genus Litocorsa also lacks palps in some species (Salazar-Vallejo \& Solis-Weiss, 1992). Santelma is here referred to the Pilargidae.

Characteristics of all known nautiliniellid genera are summarized in Table 2. These ten genera are characterized by having a muscularized foregut, paired antennae, simple neuropodial hooks, and a rounded pygidium without anal cirri, as well as by lacking notosetae and palps. Although exact habitats of two species of the genera, Flascarpia and Miura, are not known (Blake, 1993), all nautiliniellid polychaetes are highly possible to be associated with 

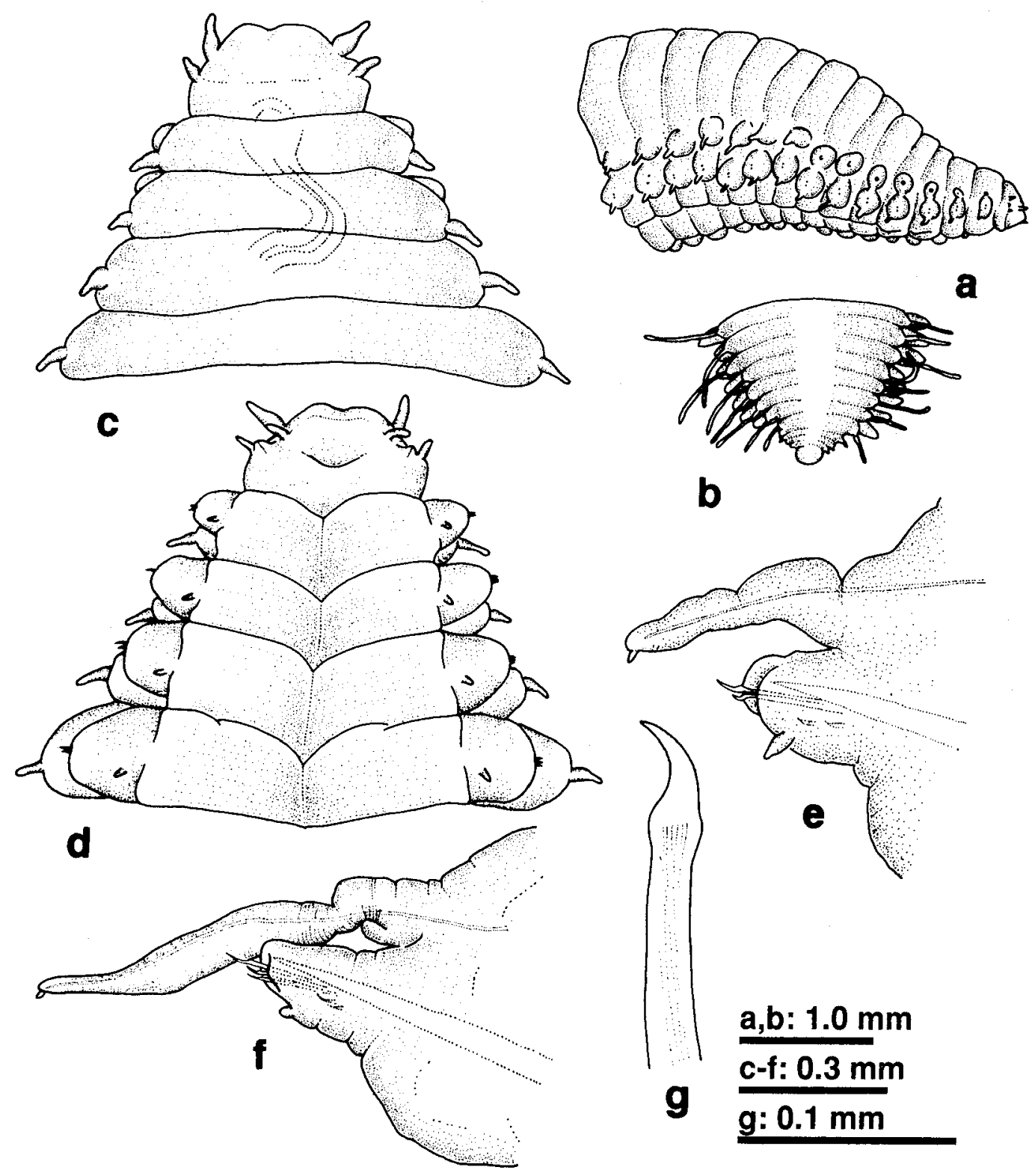

Fig. 10. Thyasiridicola branchiatus, new species (holotype). a, anterior end, lateral view ; b, posterior end, dorsal view; c, anterior end enlarged, dorsal view; d, same, ventral view; e, parapodium 27; f, parapodium $60 ; \mathrm{g}$, neuropodial hooks.

the bivalves living in hydrothermal vent and cold seep fields. Each nautiliniellid genus is associated with a certain bivalve family or one to two genera, and thus characterized also by the taxonomic group of their host bivalves (Table 2).

\section{Acknowledgments}

We thank Dr. James A. Blake, Science Application International Corporation for his critical 
Table 2. Characteristics of the genera of the Nautiliniellidae.

\begin{tabular}{|c|c|c|c|c|c|c|}
\hline $\begin{array}{c}\text { Genus } \\
\text { (Bibliography) }\end{array}$ & $\begin{array}{l}\text { Number } \\
\text { of } \\
\text { Antennae }\end{array}$ & $\begin{array}{l}\text { Tentacular } \\
\text { Segment } \\
\text { Appendages }\end{array}$ & Notoacicula & $\begin{array}{c}\text { Neuropodial } \\
\text { Hook }\end{array}$ & $\begin{array}{l}\text { Maximal Number } \\
\text { of Hooks per } \\
\text { Parapodium } \\
\text { (Additional Setae) }\end{array}$ & $\begin{array}{c}\text { Host Bivalve } \\
\text { Genus } \\
\text { (Family) }\end{array}$ \\
\hline $\begin{array}{l}\text { Nautilliniella } \\
\text { (Miura \& Laubier, } \\
1989,1990 \text { ) }\end{array}$ & 4 & $\begin{array}{l}\text { neurosetae } \\
\text { dorsal and } \\
\text { ventral cirri }\end{array}$ & stout & $\begin{array}{l}\text { stout } \\
\text { slightly curved }\end{array}$ & 1 & $\begin{array}{c}\text { Calyptogena } \\
\text { (Vesicomyidae) }\end{array}$ \\
\hline $\begin{array}{l}\text { Petrecca } \\
\text { (Blake, 1990) }\end{array}$ & 2 & ventral cirri & stout & $\begin{array}{l}\text { stout } \\
\text { slightly curved }\end{array}$ & $1-2$ & $\begin{array}{c}\text { Thyasira } \\
\text { (Thyasiridae) }\end{array}$ \\
\hline $\begin{array}{l}\text { Mytilidiphila } \\
\text { (Miura \& } \\
\text { Hashimoto, 1993) }\end{array}$ & 2 & $\begin{array}{c}\text { few setae } \\
\text { ventral cirri }\end{array}$ & stout & slender & $>20$ & $\begin{array}{l}\text { Bathymodiolus } \\
\text { near Adula } \\
\text { (Mytilidae) }\end{array}$ \\
\hline $\begin{array}{l}\text { Iheyomytilidicola } \\
\text { (this paper) }\end{array}$ & 2 & ventral cirri & stout & $\begin{array}{l}\text { stout } \\
\text { with subdistal } \\
\text { projection }\end{array}$ & $\begin{array}{c}5 \\
\text { (tridentate setae; } \\
\text { minute slender setae) }\end{array}$ & $\begin{array}{l}\text { Bathymodiolus } \\
\text { (Mytilidae) }\end{array}$ \\
\hline $\begin{array}{l}\text { Laubierus } \\
\text { (Blake, 1993) }\end{array}$ & 2 & ventral cirri & stout & $\begin{array}{l}\text { stout } \\
\text { with apical } \\
\text { fringe of bristles }\end{array}$ & $\begin{array}{c}5 \\
\text { (slender setae with } \\
\text { s mucronate tips) }\end{array}$ & (Mytilidae) \\
\hline $\begin{array}{l}\text { Shinkai } \\
\text { (Miura \& Laubier, } \\
\text { 1990; Miura \& } \\
\text { Hashimoto, 1991; } \\
\text { this paper) }\end{array}$ & 2 & $\begin{array}{c}\text { neurosetae } \\
\text { dorsal and } \\
\text { ventral cirri }\end{array}$ & slender & $\begin{array}{l}\text { stout } \\
\text { strongly curved }\end{array}$ & $\begin{array}{l}>25 \text {, anteriorly } \\
10, \text { posteriorly }\end{array}$ & $\begin{array}{c}\text { Calyptogena } \\
\text { (Vesicomyidae) }\end{array}$ \\
\hline $\begin{array}{l}\text { Natsushima } \\
\text { (Miura \& Laubier, } \\
\text { 1990; this paper) }\end{array}$ & 2 & $\begin{array}{l}\text { neurosetae } \\
\text { dorsal and } \\
\text { ventral cirri }\end{array}$ & $\begin{array}{l}\text { slender } \\
\text { or } \\
\text { absent }\end{array}$ & $\begin{array}{l}\text { stout } \\
\text { slightly curved }\end{array}$ & $\begin{array}{c}2-3 \\
\text { (bifurcate simple } \\
\text { setae) }\end{array}$ & $\begin{array}{c}\text { Acharax } \\
\text { Solemya } \\
\text { (Solemyidae) }\end{array}$ \\
\hline $\begin{array}{l}\text { Thyasiridicola } \\
\text { (this paper) }\end{array}$ & 2 & $\begin{array}{l}\text { dorsal and } \\
\text { ventral cirri }\end{array}$ & slender & $\begin{array}{l}\text { stout } \\
\text { slightly curved }\end{array}$ & 4 & $\begin{array}{c}\text { Conchocele } \\
\text { (Thyasiridae) }\end{array}$ \\
\hline $\begin{array}{l}\text { Flascarpia } \\
\text { (Blake, 1993) }\end{array}$ & 2 & ventral cirri & absent & $\begin{array}{l}\text { stout } \\
\text { with subterminal } \\
\text { protuberances }\end{array}$ & $7-8$ & ? \\
\hline $\begin{array}{l}\text { Miura } \\
\text { (Blake, 1993) }\end{array}$ & 0 & 4 modified cirri & absent & $\begin{array}{l}\text { slender } \\
\text { slightly curved }\end{array}$ & $4-6$ & $?$ \\
\hline
\end{tabular}

reading of the first manuscript and helpful suggestions. Thanks are also due to Dr. S. Ohta and Dr. Y. Nozaki of Ocean Research Institute, University of Tokyo for their kind offer of a part of specimens examined in this study, as well as the staff of JAMSTEC for their assistance at the sampling. This work was supported in part by grants-in-aid for the first author from the Ministry of Education, Science, Culture and Sports, Japan (No. 06839021) and from Kato Foundation for the Promotion of the Bioscience Researches.

\section{References}

Åkesson, B. 1967. The embryology of the polychaete Eunice kobiensis. Acta Zool., 48: 141-192. Blake, J.A. 1990. A new genus and species of Polychaeta commensal with a deep-sea thyasirid clam. Proc. Biol. Soc. Washington, 103: 681-686.

Blake, J.A. 1993. New genera and species of deep-sea polychaetes of the family Nautiliniellidae from the Gulf of Mexico and the Eastern Pacific. Proc. Biol. Soc. Washington, 106: 147-157.

Day, J.H. 1967. A monograph on the Polychaeta of Southern Africa. British Mus. Nat. Hist. 
Publ., 656: 1-878.

Dean, H.K. 1992. A new arabellid polychaete living in the mantle cavity of deep-sea wood boring bivalves (Family Pholadidae). Proc. Biol. Soc. Washington, 105: 224-232.

Fauchald, K. 1972. Benthic polychaetous annelids from deep water off western Mexico and adjacent areas in the eastern Pacific Ocean. Allan Hancock Monogr. Mar. Biol., 7: 1-575.

Fauchald, K. 1992. A review of the genus Eunice (Polychaeta: Eunicidae) based upon type material. Smithsonian Contrib. Zool., 532: 1-422.

Hartman, O. \& Boss, K.J. 1966. Antonbruunia viridis, a new inquiline annelid with dwarf males, inhabiting a new species of pelecypod, Lucina fosteri, in the Mozambique Channel. Ann. Mag. Nat. Hist. ser. 13, 8: 177-186.

Hashimoto, J. \& Okutani, T. 1994. Four new mytilid mussels associated with deepsea chemosynthetic communities around Japan. Venus (Jap. J. Malac.), 53: 61-83.

Miura, T. 1986. Japanese polychaetes of the genera Eunice and Euniphysa: Taxonomy and branchial distribution patterns. Publ. Seto Mar. Biol .Lab., 31: 269-325.

Miura, T. \& Hashimoto, J. 1991. Two new branchiate scale-worms (Polynoidae: Polychaeta) from the hydrothermal vent of the Okinawa Trough and the volcanic seamount off Chichijima Island. Proc. Biol. Soc. Washington, 104: 166-174.

Miura, T. \& Hashimoto, J. 1993. Mytilidiphila, a new genus of nautiliniellid polychaetes living in the mantle cavity of deep-sea mytilid bivalves collected from the Okinawa Trough. Zool. Sci., 10: $169-174$.

Miura, T. \& Laubier, L. 1989. Nautilina calyptogenicola, a new genus and species of parasitic polychaete on a vesicomyid bivalve from the Japan Trench, representative of a new family Nautilinidae. Zool. Sci., 6: 387-390.

Miura, T. \& Laubier, L. 1990. Nautiliniellid polychaetes collected from the Hatsushima cold seep site in Sagami Bay, with descriptions of new genera and species. Zool. Sci., 7: 319- 325.

Miura, T. \& Ohta, S. 1991. Two polychaete species from the deep-sea hydrothermal vents in the Okinawa Trough. Zool. Sci., 8: 383-387.

Ohta, S. 1990. Ecological observations and remarks on the cold seep communities in Sagami Bay, central Japan. Proc. JAMSTEC Symp. deep-sea Res., 6: 181-195. [In Japanese with English abstract]

Okutani, T. 1957. Two new species of bivalves from the deep water in Sagami Bay collected by the R.V. Soyo-Maru. Bull. Tokai Reg. Fish. Res. Lab., 17: 27-30.

Okutani, T., Hashimoto, J. \& Fujikura, K. 1992. A new species of vesicomyid bivalve associated with hydrothermal vents near Amani-Oshima Island, Japan. Venus (Jap. J. Malac.), 51: 225-233.

Pettibone, M.H. 1961. New species of polychaete worms from the Atlantic Ocean, with revision of the Dorvilleidae. Proc. Biol. Soc. Washington, 74: 167-186.

Pettibone, M.H. 1984. A new scale-worm commensal with deep-sea mussels on the Galapagos hydrothermal vent (Polychaeta: Polynoidae). Proc. Biol. Soc. Washington, 97: 226-239.

Pettibone, M.H. 1986. A new scale-worm commensal with deep-sea mussels in the seep-sites at the Florida Escarpment in the Eastern Gulf of Mexico (Polychaeta: Polynoidae: Branchipolynoinae). Proc. Biol. Soc. Washington, 99: 444-451.

Rozbaczylo, N. \& Cañete, J.I. 1993. A new species of scale-worm, Harmothoe commensalis (Polychaeta: Polynoidae), from mantle cavities of two Chilean clams. Proc. Biol. Soc. Washington, 106: $666-672$.

Salazar-Vallejo, S.I. \& Solís-Weiss, V. 1992. Biogeography of the pilargid polychaetes (Polychaeta Pilargidae) of the subfamily Synelminae. Tulane Stud. Zool. Bot. Suppl. Publ., 1: 273-284. 